\title{
Perkinsus marinus in coastal Georgia, USA, following a prolonged drought
}

\author{
A. Power ${ }^{1, *}$, B. McCrickard ${ }^{1}$, M. Mitchell ${ }^{1}$, E. Covington ${ }^{1}$, M. Sweeney-Reeves ${ }^{1}$, \\ K. Payne ${ }^{2}$, R. Walker ${ }^{1}$ \\ ${ }^{1}$ University of Georgia Marine Extension Service, Shellfish Research Laboratory, 20 Ocean Science Circle, Savannah, \\ Georgia 31411-1011, USA \\ ${ }^{2}$ University of Georgia Marine Extension Service, 220 Marine Sciences Building, Athens, Georgia 30602-3636, USA
}

\begin{abstract}
Oysters Crassostrea virginica are 'keystone' estuarine species in the southeastern USA, providing essential fish habitat, food for human consumption, filtration of water bodies, and protection against shoreline erosion. Relatively few oyster pathology studies have been conducted in Georgia. The parasitic protozoan Perkinsus marinus was first observed here in the 1960s, but has not been investigated since the late 1990s, when increasing oyster infection levels were apparent. In the late 1990s and early 2000s, the region suffered a prolonged drought, resulting in elevated salinities and the proliferation of various diseases in the marine environment. By 2003, salinities had returned to normal levels, but the effect of the drought on oysters was unknown. In June 2003, oyster reefs throughout Chatham County were sampled to evaluate the prevalence and intensity of $P$. marinus. The disease appears to have remained prevalent in the coastal waters of Georgia (100\% prevalence at some sites), but the intensity was low, ranging from 0 to 1.83 on a scale where heavy infections rated a score of 5 . While the disease did not occur at levels high enough to cause oyster mortalities, further monitoring, particularly on a temporal scale, is warranted.
\end{abstract}

KEY WORDS: Oyster · Perkinsus marinus · Prevalence $\cdot$ Intensity $\cdot$ Drought $\cdot$ Georgia

\section{INTRODUCTION}

In Georgia, USA, the eastern oyster Crassostrea virginica grows primarily intertidally, in salinities ranging from 15 to $>30 \mathrm{ppt}$, and forms dense reefs. Georgia's oyster resources were once immense and supported a thriving cannery-based industry. However, overfishing, pollution, disease, and environmental factors have dramatically reduced oyster populations, and the fishery exists today primarily to serve a fall and winter sack trade for local 'roasts.' Oyster roasts are social events where locals gather to steam oysters over a bonfire.

Environmental factors such as temperature and salinity affect the health and productivity of shellfish populations directly by affecting processes such as filtration rate, respiration, and reproduction, and indirectly by affecting the abundance and feeding rate of predators and the dynamics of disease (Kim et al. 1999). Disease can inhibit growth, lower the condition index, disrupt filtering activities, reduce the reproductive capacity, inhibit larval development, and reduce spatfall (O'Beirn et al. 1994, Ford \& Tripp 1996, Paynter 1996).

One of the most problematic oyster diseases in the United States is caused by the parasitic protozoan Perkinsus marinus. The origins of the disease remain uncertain; however, it was first identified as the cause of epizootic oyster mortalities in the Gulf of Mexico in 1948 (Mackin et al. 1950). Since then, the parasite has been reported in oysters from Maine to Florida and throughout the Gulf to Mexico (Quick \& Mackin 1971, Andrews 1988, Craig et al. 1989, Lewis et al. 1992, Ford 1996, Soniat 1996). The parasites proliferate most rapidly above a temperature of $25^{\circ} \mathrm{C}$ and salinities above 12 ppt (Bobo et al. 1997). As a result, the major 
infective period in most areas occurs between May and October.

In comparison to oyster populations in the northern USA, relatively few pathology studies have been conducted in the southeast. In 1966 and 1968, a histological study (tissue sections) of oysters from coastal Georgia was conducted to determine the status of oyster agents and parasites as part of a coastwide Atlantic survey (Lewis et al. 1992). At that time, oyster populations in South Carolina, North Carolina, and the Gulf of Mexico region were experiencing major mortalities and elevated Perkinsus marinus infections (Lewis et al. 1992, Bobo et al. 1997, O'Beirn et al. 1997). The prevalence of the disease in Georgia was low, ranging from 0 to a maximum of $44 \%$ over the study area, and intensities were not quantified (Lewis et al. 1992). The next Georgia survey was conducted between 1985 and 1987, and the prevalence of the disease was observed to have increased (up to $100 \%$ ) causing mortalities of epizootic proportions (Lewis et al. 1992). Ray's fluid thioglycollate medium assay (Ray 1952) was used to determine a mean intensity index of 3.9 (light-moderate) on a scale of 1 (very light) to 9 (very heavy). Later, O'Beirn et al. (1997) reported a maximum prevalence of $100 \%$ and intensity of 3.2 (light medium) using the same techniques in the Duplin River (Sapelo Island, Georgia). The latter study used the Quick \& Mackin (1971) scale from 0 (no infection) to 6 (very high infection) to quantify infection.

Drought conditions occurring in the late 1990s and early 2000s altered the salinity patterns of Georgia's estuarine systems (Fig. 1). Mean annual salinities for 1999, 2000, 2001, and 2002 at the Marine Extension

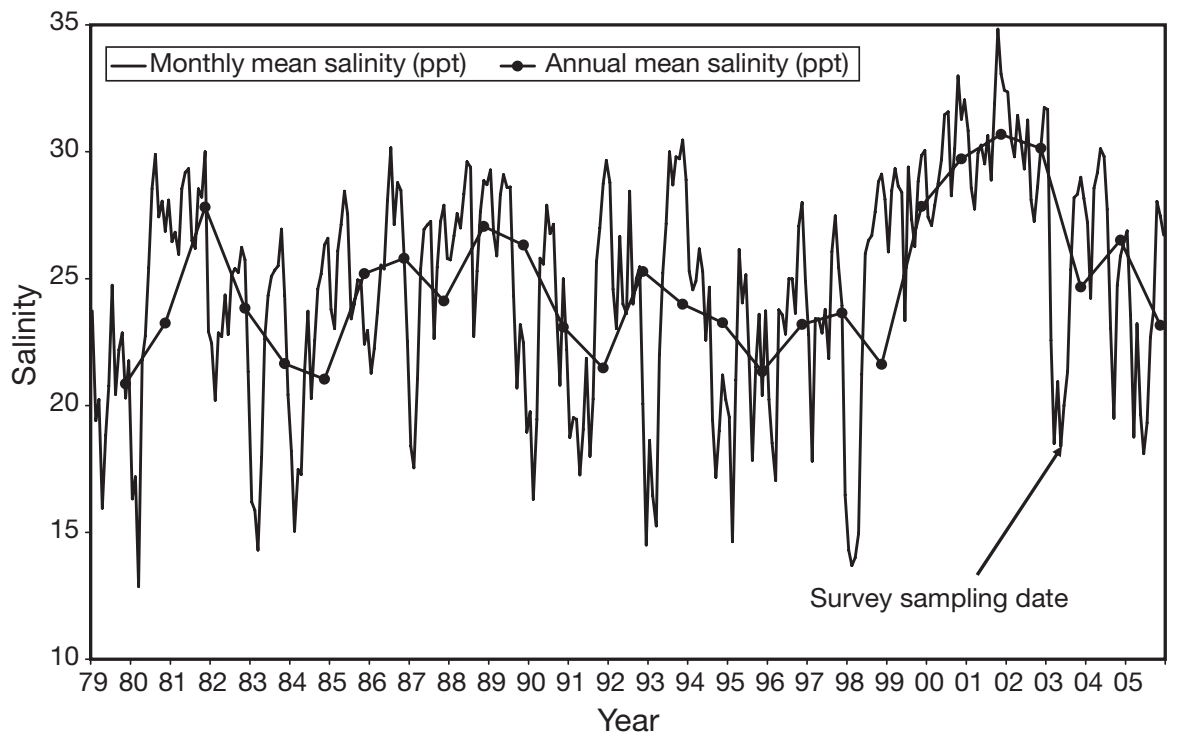

Fig. 1. Mean monthly and annual salinity (ppt) recorded at Site 5 (see Fig. 2) between February 1979 and February 2006. Surface water salinity data were recorded daily at 08:00 h (Monday to Friday)
Service dock identified in Fig. 1 attained values that exceeded all records back to 1979. An increase in salinity in the region encouraged the spread of diseases, including the parasitic dinoflagellate Hematodinium sp., which has contributed to the collapse of the blue crab Callinectes sapidus fishery (Lee \& Frischer 2004). In addition, higher salinities are thought to be responsible for recent mortality events of the marsh grass Spartina alterniflora. It is possible that Perkinsus marinus had similarly proliferated during this period; however, there have been no recent studies on the status of oyster disease in the state. Given that the drought has recently ended (Fig. 1), our goal was to provide an assessment of the biological response of oysters to the prolonged drought by documenting prevalence and intensity of the disease in coastal Chatham County, Georgia.

\section{MATERIALS AND METHODS}

Oysters were collected from 67 sites along the coast of Chatham County, Georgia, from 9 to 14 June 2003 (Fig. 2). The sites were selected by trying to locate the major beds mapped during a previous oyster distribution survey in the area (Fig. 2; Johnson et al. 1974). At each site, the surface water temperature $\left({ }^{\circ} \mathrm{C}\right)$, salinity (ppt), and GPS location were recorded. Oyster clumps were then selected from the middle of each bed and broken up, and 24 living oysters (shells closed tightly) were chosen. Twelve were used to determine a condition index and another 12 were used to determine sex ratios and the prevalence and intensity of Perkinsus marinus.

Condition index was determined based on the methods of Lawrence \& Scott (1982). Each oyster was measured for shell length (umbo to tip, $\mathrm{mm}$ ) and weighed (total weight, $\mathrm{g}$ ). Subsequently the shell was opened and the meat was placed on an aluminum foil dish and then dried in an oven at $67^{\circ} \mathrm{C}$ for $48 \mathrm{~h}$ to obtain a dry weight. Empty oyster shells were also dried at room temperature for $24 \mathrm{~h}$ and subsequently reweighed. The internal cavity volume was determined by subtracting the shell weight $(g)$ from the total weight (meat and shell). The condition index was calculated by the following formula: (dry meat weight in g) (100) / (internal cavity volume in $\mathrm{cm}^{3}$ ).

The shell lengths ( $\mathrm{mm}$ ) of the remaining specimens were determined, and a $5 \mathrm{~mm}$ section of the 


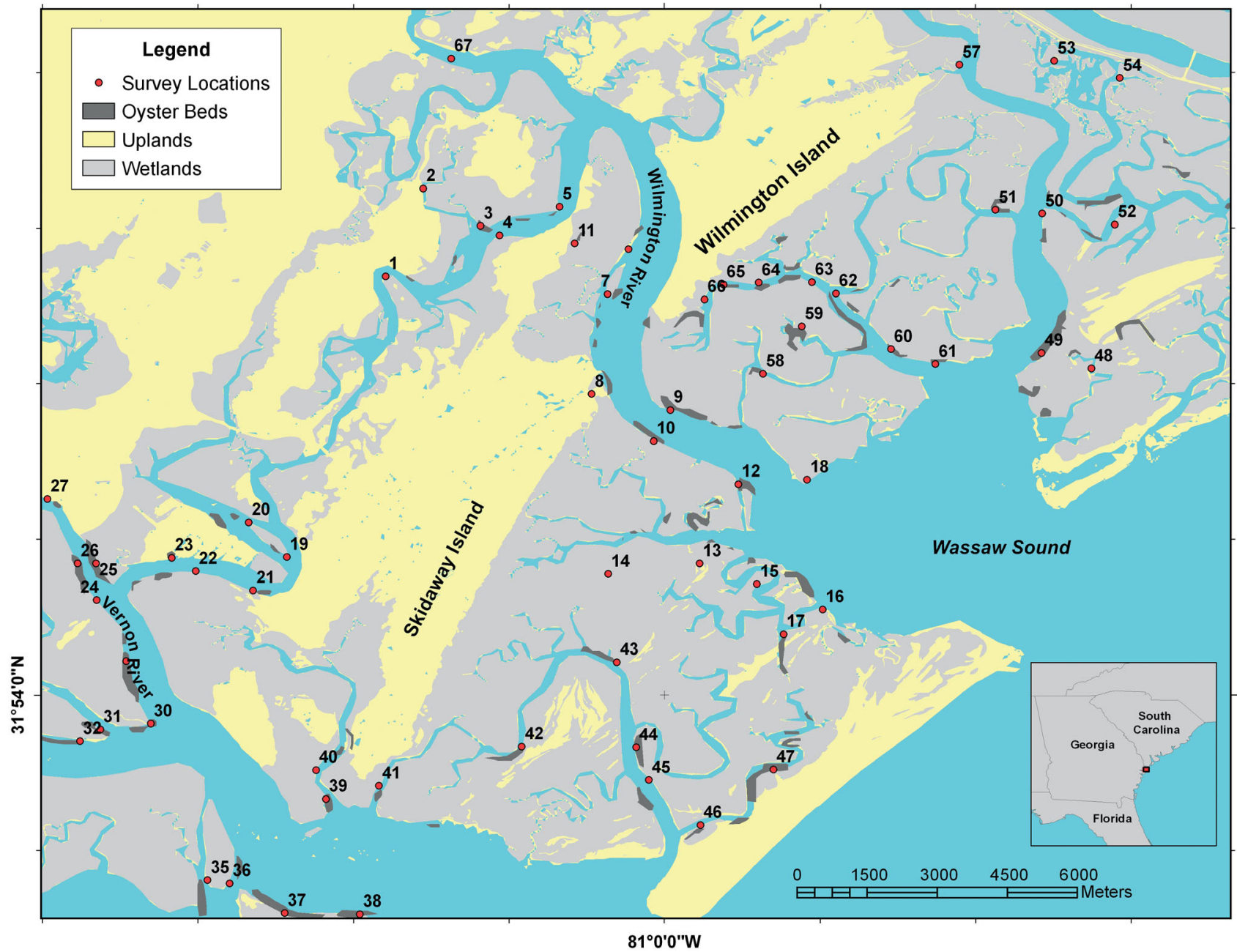

Fig. 2. Disease survey locations in Chatham County, Georgia. Also shown is the distribution of oyster beds as mapped in 1966-1967 (after Johnson et al. 1974)

gonad and $1 \mathrm{~cm}^{2}$ of the rectum were dissected from each one. The gonadal tissue was fixed in $10 \%$ formalin (buffered in seawater), stored in $70 \%$ ethanol, and processed histologically according to procedures outlined by Howard \& Smith (1983). Slides were stained with Harris's hematoxylin and eosin to allow the microscopic examination of gonadal tissue and the determination of sex ratios. Ray's fluid thioglycollate medium assay (Ray 1952) was used to assay rectal tissue according to procedures outlined by Powell \& Ellis (1998). Each sample was examined microscopically with a dissecting microscope, and an intensity index of Perkinsus marinus infection was assigned according to Craig et al.'s (1989) semiquantative scale. Mean infection intensity indices were calculated for each site by averaging the intensity index score of each oyster including uninfected individuals (score $=0$ ) at each site.

In an effort to document recruitment differences across the study area, 3 longitudinally grooved oyster spat collection sticks (25.4 mm diameter; Aquatic Eco- systems) were staked into the mud at the base of each oyster bed that was sampled between 9 and 14 June 2003. At least $60 \mathrm{~cm}$ of the stick were left exposed. After $6 \mathrm{wk}$, all sticks were retrieved, and a $12 \mathrm{~cm}$ midsection (approximate surface area of $100 \mathrm{~cm}^{2}$ ) of each stick was counted for the number of attached spat.

\section{RESULTS}

Salinities ranged from 8 to $30 \mathrm{ppt}$ and temperatures from 27 to $32^{\circ} \mathrm{C}$ over the study area (Table 1, Fig. 1). The size and condition index of oysters and spat settlement varied according to location (Table 1). Mean sizes ranged between 49 and $97 \mathrm{~mm}$; mean condition indices ranged from 1.70 to 12.15 ; and the mean number of spat ranged from 0 to 223 per $100 \mathrm{~cm}^{2}$.

Perkinsus marinus prevalence ranged from $0 \%$ at one location to $100 \%$ at 12 locations (Table 1) and mean infection intensity indices per site ranged from 0 
Table 1. Perkinsus marinus. Prevalence (\%), infection intensity (scale 0-5), and shell length (mm) for oysters ( $\mathrm{N}=12$ ) collected from 67 sites in Chatham County, Georgia. Also presented are the sex ratios (male to female, M/F), condition indices, recruitment rates (number of spat per $100 \mathrm{~cm}^{2}$ ), and water temperature and salinity data determined for these same locations. Data from each site are ranked according to increasing salinity. nd = no data available

\begin{tabular}{|c|c|c|c|c|c|c|c|c|c|c|}
\hline \multirow{2}{*}{$\begin{array}{l}\text { Site } \\
\text { no. }\end{array}$} & \multirow{2}{*}{$\begin{array}{c}\text { Salinity } \\
\text { (ppt) }\end{array}$} & \multirow{2}{*}{$\begin{array}{c}\text { Temp. } \\
\left({ }^{\circ} \mathrm{C}\right)\end{array}$} & \multirow{2}{*}{$\begin{array}{c}\text { Mean } \\
\text { no. } \\
\text { spat per } \\
100 \mathrm{~cm}^{2}\end{array}$} & \multicolumn{3}{|c|}{ Condition index sample } & \multirow[b]{2}{*}{$\begin{array}{c}\overline{\text { Prevalence }} \\
(\%)\end{array}$} & \multicolumn{2}{|c|}{ Disease sample - } & \multirow[b]{2}{*}{$\begin{array}{c}\text { Mean } \\
\text { infection } \\
\text { intensity }\end{array}$} \\
\hline & & & & $\begin{array}{c}\text { Mean } \\
\text { length } \\
(\mathrm{mm})\end{array}$ & $\begin{array}{l}\text { Mean } \\
\text { weight } \\
\text { (g) }\end{array}$ & $\begin{array}{l}\text { Mean } \\
\text { condition } \\
\text { index }\end{array}$ & & $\begin{array}{l}\mathrm{M} / \mathrm{F} \\
\text { ratio }\end{array}$ & $\begin{array}{c}\text { Mean } \\
\text { length } \\
\text { (mm) }\end{array}$ & \\
\hline 33 & 8 & 29 & 1.00 & 68.33 & 23.01 & 9.97 & 33.33 & 1.00 & 53.25 & 0.14 \\
\hline 34 & 9 & 28 & 0.00 & 96.92 & 59.41 & 9.11 & 66.67 & 1.00 & 47.17 & 0.22 \\
\hline 67 & 13 & 29 & nd & 92.33 & 51.92 & 3.79 & 42.00 & 2.33 & 47.00 & 0.19 \\
\hline 1 & 15 & 27 & 132.33 & 92.33 & 51.92 & 3.79 & 66.67 & 0.50 & 96.75 & 0.44 \\
\hline 27 & 15 & 31 & 118.67 & 67.42 & 38.10 & 7.41 & 91.67 & 1.40 & 65.83 & 0.58 \\
\hline 32 & 15 & 30 & 42.67 & 64.21 & 42.32 & 7.67 & 100.00 & 2.00 & 59.25 & 0.83 \\
\hline 57 & 15 & 31 & 35.67 & 94.64 & 67.50 & 8.97 & 41.67 & 0.50 & 60.00 & 0.33 \\
\hline 28 & 16 & 30 & 16.00 & 73.13 & 36.51 & 8.04 & 75.00 & 1.00 & 63.42 & 0.28 \\
\hline 25 & 18 & 29 & 168.00 & 62.79 & 29.76 & 7.55 & 91.67 & 0.57 & 53.74 & 0.36 \\
\hline 30 & 18 & 29 & 24.33 & 61.67 & 30.18 & 10.04 & 41.67 & 0.43 & 49.17 & 0.19 \\
\hline 31 & 18 & 31 & 193.33 & 70.38 & 41.78 & 7.38 & 58.33 & 1.00 & 52.08 & 0.42 \\
\hline 2 & 19 & 29 & 1.67 & 49.57 & 25.68 & 7.09 & 91.67 & 0.71 & 52.08 & 1.03 \\
\hline 5 & 19 & 29 & 101.67 & 71.67 & 33.93 & 8.87 & 0.00 & 1.20 & 71.08 & 0.00 \\
\hline 24 & 19 & 29 & 7.33 & 89.96 & 52.21 & 6.87 & 58.33 & 2.33 & 72.50 & 0.19 \\
\hline 26 & 19 & 29 & 14.33 & 79.75 & 39.36 & 7.01 & 100.00 & 2.33 & 63.71 & 0.92 \\
\hline 29 & 19 & 30 & 54.33 & 73.33 & 46.33 & 8.73 & 33.33 & 2.00 & 57.50 & 0.14 \\
\hline 7 & 20 & 28 & 70.33 & 66.42 & 29.77 & 9.36 & 75.00 & 1.00 & 74.29 & 0.81 \\
\hline 23 & 20 & 29 & 135.00 & 63.50 & 28.18 & 2.76 & 91.67 & 2.33 & 47.00 & 0.61 \\
\hline 4 & 21 & 28 & 19.00 & 79.63 & 28.38 & 9.44 & 83.33 & 1.40 & 73.50 & 0.33 \\
\hline 3 & 22 & 28 & 1.67 & 81.67 & 39.43 & 6.35 & 66.67 & 0.33 & 65.83 & 0.31 \\
\hline 11 & 22 & 29 & 0.33 & 91.17 & 39.75 & 8.24 & 100.00 & 0.83 & 94.67 & 1.03 \\
\hline 21 & 22 & 29 & 143.00 & 72.42 & 28.53 & 7.09 & 66.67 & 1.00 & 76.17 & 0.25 \\
\hline 22 & 22 & 30 & 103.67 & 86.25 & 46.52 & 5.61 & 83.33 & 2.00 & 70.42 & 0.30 \\
\hline 35 & 22 & 29 & 2.33 & 77.25 & 40.26 & 6.36 & 83.33 & 0.71 & 53.92 & 0.53 \\
\hline 39 & 22 & 29 & 50.67 & 79.18 & 28.17 & 8.61 & 66.67 & 1.40 & 67.92 & 0.33 \\
\hline 40 & 22 & 29 & 9.67 & 66.14 & 21.44 & 9.11 & 75.00 & 1.33 & 73.08 & 0.47 \\
\hline 6 & 24 & 28 & 12.33 & 83.42 & 35.04 & 7.44 & 100.00 & 0.83 & 102.46 & 1.06 \\
\hline 20 & 24 & 29 & 0.00 & 84.63 & 61.16 & 6.79 & 100.00 & 0.83 & 94.42 & 1.36 \\
\hline 36 & 24 & 28 & 7.00 & 53.38 & 18.33 & 10.01 & 50.00 & 0.57 & 38.67 & 0.17 \\
\hline 50 & 24 & 29 & 162.67 & 93.00 & 39.68 & 7.56 & 25.00 & 0.83 & 64.92 & 0.08 \\
\hline 52 & 24 & 29 & 15.33 & 65.77 & 51.04 & 6.48 & 83.33 & 1.40 & 52.42 & 0.42 \\
\hline 53 & 24 & 30 & 40.00 & 58.25 & 58.33 & 7.43 & 91.67 & 2.00 & 63.33 & 0.61 \\
\hline 54 & 24 & 32 & 3.33 & 73.58 & 49.63 & 8.33 & 50.00 & 1.00 & 56.17 & 0.44 \\
\hline 8 & 25 & 30 & 27.33 & 88.04 & 28.20 & 7.06 & 83.33 & 0.33 & 86.63 & 0.61 \\
\hline 9 & 25 & 29 & nd & 66.58 & 30.65 & 8.04 & 100.00 & 2.00 & 72.83 & 0.83 \\
\hline 13 & 25 & 28 & 17.00 & 75.36 & 30.38 & 6.37 & 100.00 & 0.71 & 91.88 & 1.50 \\
\hline 14 & 25 & 28 & 64.67 & 59.22 & 19.08 & 12.15 & 58.33 & 1.00 & 64.08 & 0.28 \\
\hline 16 & 25 & 30 & 24.00 & 73.75 & 28.24 & 6.34 & 100.00 & 0.50 & 64.83 & 0.78 \\
\hline 17 & 25 & 29 & 33.67 & 66.95 & 27.87 & 9.43 & 100.00 & 0.38 & 59.00 & 0.81 \\
\hline 18 & 25 & 31 & 36.33 & 79.68 & 33.86 & 1.70 & 66.67 & 1.00 & 60.33 & 0.28 \\
\hline 41 & 25 & 29 & 84.67 & 83.65 & 34.41 & 7.61 & 75.00 & 0.33 & 83.67 & 0.55 \\
\hline 42 & 25 & 29 & 24.67 & 90.85 & 49.13 & 7.14 & 75.00 & 1.00 & 61.83 & 0.78 \\
\hline 49 & 25 & 29 & 54.33 & 70.26 & 24.13 & 8.72 & 50.00 & 2.67 & 61.92 & 0.36 \\
\hline 51 & 25 & 29 & 99.00 & 72.71 & 32.68 & 6.35 & 58.33 & 1.00 & 52.67 & 0.47 \\
\hline 58 & 25 & 30 & nd & 87.64 & 44.71 & 7.23 & 50.00 & 0.83 & 57.83 & 0.39 \\
\hline 61 & 25 & 29 & 54.33 & 82.66 & 42.82 & 7.13 & 50.00 & 1.00 & 65.00 & 0.33 \\
\hline 65 & 25 & 29 & 60.67 & 78.63 & 49.17 & 6.82 & 66.67 & 3.00 & 69.50 & 0.28 \\
\hline 10 & 26 & 28 & 0.33 & 82.00 & 32.92 & 9.23 & 100.00 & 0.22 & 87.73 & 1.00 \\
\hline 12 & 26 & 28 & 78.33 & 89.38 & 39.15 & 6.38 & 91.67 & 0.71 & 78.75 & 0.86 \\
\hline 37 & 26 & 29 & 110.67 & 67.61 & 24.17 & 6.83 & 25.00 & 4.00 & 49.92 & 0.08 \\
\hline 45 & 26 & 29 & 102.00 & 78.80 & 35.28 & 7.66 & 25.00 & 0.50 & 66.64 & 0.09 \\
\hline 46 & 26 & 31 & 59.67 & 79.16 & 29.28 & 7.81 & 25.00 & 2.00 & 71.50 & 0.08 \\
\hline 47 & 26 & 32 & 7.00 & 67.68 & 33.03 & 8.19 & 25.00 & 2.00 & 54.25 & 0.08 \\
\hline 55 & 26 & 29 & 43.67 & 68.75 & 43.69 & 5.06 & 58.33 & 1.20 & 62.00 & 0.25 \\
\hline 59 & 26 & 31 & nd & 91.64 & 57.98 & 7.45 & 41.67 & 1.75 & 62.67 & 0.14 \\
\hline 15 & 27 & 29 & 117.00 & 88.86 & 28.14 & 6.40 & 100.00 & 0.33 & 80.83 & 0.97 \\
\hline 19 & 27 & 29 & 1.33 & 80.38 & 41.37 & 7.29 & 100.00 & 0.71 & 70.29 & 1.83 \\
\hline 38 & 27 & 29 & 36.00 & 62.44 & 24.38 & 9.77 & 58.33 & 1.00 & 58.67 & 0.19 \\
\hline 64 & 27 & 29 & 142.33 & 67.56 & 43.48 & 7.86 & 27.27 & 0.80 & 45.27 & 0.12 \\
\hline 66 & 27 & 30 & 0.67 & 67.18 & 32.78 & 8.15 & 75.00 & 1.40 & 56.58 & 0.55 \\
\hline 44 & 28 & 29 & nd & 79.40 & 44.28 & 9.48 & 58.33 & 1.20 & 67.00 & 0.19 \\
\hline 62 & 28 & 29 & 57.33 & 80.32 & 34.65 & 7.03 & 58.33 & 3.00 & 62.50 & 0.25 \\
\hline 43 & 29 & 30 & 61.00 & 77.68 & 38.33 & 7.75 & 66.67 & 0.57 & 68.00 & 0.39 \\
\hline 48 & 30 & 28 & 60.00 & 72.01 & 39.58 & 8.14 & 33.33 & 1.40 & 64.33 & 0.14 \\
\hline 56 & 30 & 32 & 41.00 & 71.61 & 42.25 & 7.81 & 66.67 & 2.00 & 51.17 & 0.28 \\
\hline 60 & 30 & 29 & 160.33 & 81.94 & 42.81 & 8.10 & 33.33 & 0.71 & 50.58 & 0.22 \\
\hline 63 & 30 & 29 & 222.67 & 75.69 & 39.43 & 5.78 & 41.67 & 1.20 & 62.00 & 0.17 \\
\hline
\end{tabular}




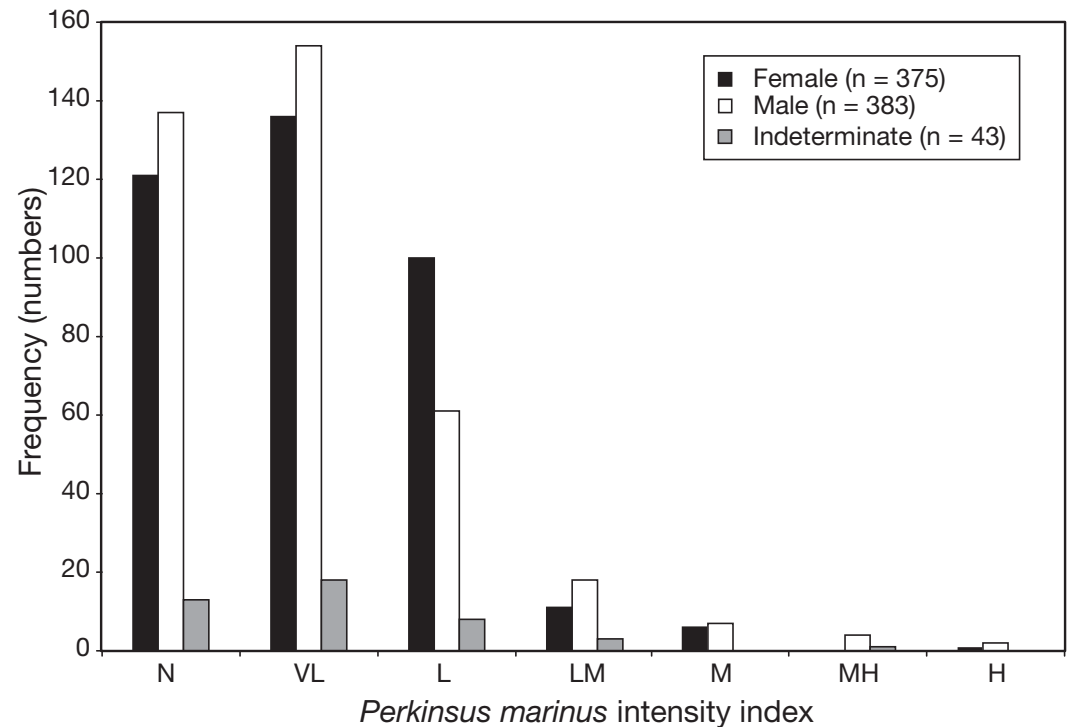

Fig. 3. Crassostrea virginica infected by Perkinsus marinus. Frequency distribution of male, female, and indeterminate oysters at each disease intensity index level $(\mathrm{N}=$ negative, $\mathrm{VL}=$ very light, $\mathrm{L}=$ light, $\mathrm{LM}=$ light-moderate, $\mathrm{M}=$ moderate, $\mathrm{MH}=$ moderately heavy, $\mathrm{H}=$ heavy) significance level, negative correlations were revealed between the infection index and spat settlement, and the male/female ratio. Prevalence was negatively correlated to oyster weight, and to spat settlement.

At the 95\% significance level, positive correlations were detected between the infection index, shell length, and prevalence. Surface water temperatures were correlated with the male/female ratio and oyster weight, and shell length was also correlated with weight. While significant correlations were not detected between temperature and infection indices, a good linear fit was achieved by regressing the mean infection index calculated for each temperature between 28 and $32^{\circ} \mathrm{C}\left(27^{\circ} \mathrm{C}\right.$ was excluded, since there was only one value; $28^{\circ} \mathrm{C}, 11$ values; $29^{\circ} \mathrm{C}, 36$ values; $30^{\circ} \mathrm{C}$, 10 values; $31^{\circ} \mathrm{C}$, 6 values; $32^{\circ} \mathrm{C}, 3$ values); the regression equation was as follows: Infection index $=(-0.08)$ (Temperature in $\left.{ }^{\circ} \mathrm{C}\right)+2.96, \mathrm{R}^{2}=0.91$. Repeating for tempera-

to 1.83 (negative to light-moderate). The mean prevalence and intensity over the entire study were $66 \%$ and 0.51 (very light), respectively. Of the 801 oysters examined, 375 oysters were female, 383 were male, and 43 were sexually indeterminate (Fig. 3). Approximately $72 \%$ of the examined oysters had no infection or were very lightly infected. Thirty-two percent of female and $36 \%$ of male oysters had no infection, while $36 \%$ of female and $40 \%$ of male oysters were very lightly infected. There did not appear to be any gender differences in the remaining oysters, which were lightly to heavily infected (light: $27 \%$ females, $16 \%$ males; light-moderate: 3\% females, 5\% males; moderate: $2 \%$ females, $2 \%$ males; moderate-heavy: no females, $1 \%$ males; heavy: <1 \% for both sexes).

The study locations were ranked according to salinity data and divided into 6 regimes $(\leq 10,10-14,15-19$, $20-24,25-29$, and $\geq 30$ ppt). A single representative value (mean) was calculated for spat settlement, disease prevalence and intensity, sex ratio, and oyster lengths within salinity groupings (Fig. 4). Shell length and Perkinsus marinus prevalence and intensity appear to follow the same trend (i.e. increasing from $\leq 10$ to $24 \mathrm{ppt}$, and decreasing from 25 to $\geq 30 \mathrm{ppt}$ ). The relationship between disease prevalence and intensity, water quality, and biological parameters was further investigated using Spearman's rank correlation coefficients (Table 2).

At the $90 \%$ significance level, negative correlations were detected between infection and condition indices, shell length and condition indices, and between the male/female ratio and the prevalence. At the $95 \%$ regression: Prevalence $=(-6.56)\left(\right.$ Temperature in $\left.{ }^{\circ} \mathrm{C}\right)+$ 260.03, $\mathrm{R}^{2}=0.68$.

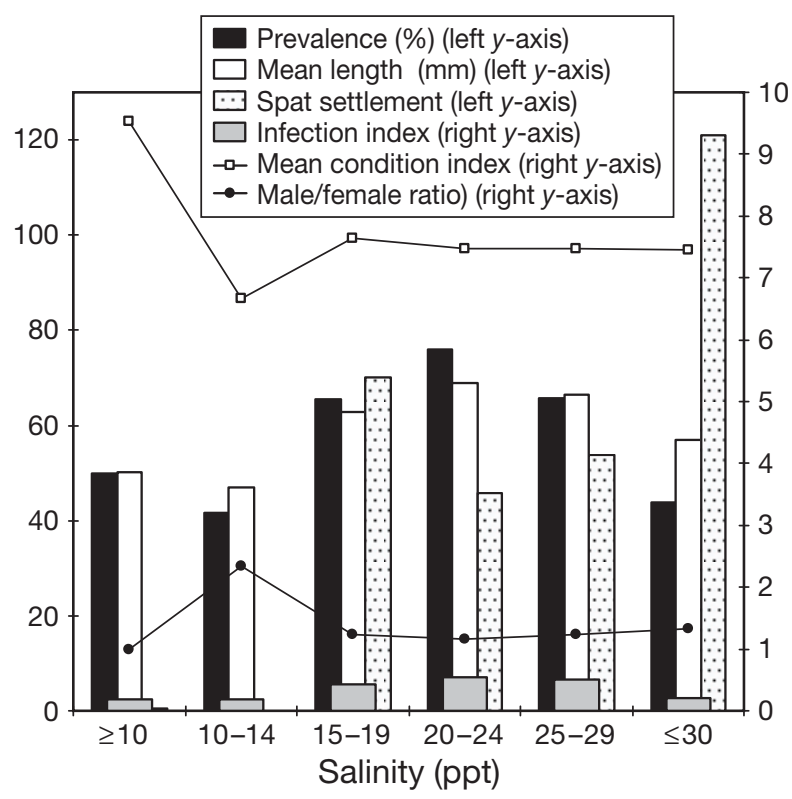

Fig. 4. Crassostrea virginica infected by Perkinsus marinus. Disease prevalence (\%), mean oyster shell lengths (mm), spat settlement rates (number of spat per $100 \mathrm{~cm}^{2}$ ), infection intensity indices (scale $0-5$ ), condition indices, and sex ratios (male to female) for oysters $(\mathrm{N}=12)$ collected from 67 sites in Chatham County, Georgia. A single representative value was calculated for each site, ranked according to sampling salinities and means were calculated for increasing salinity regimes $(\leq 10,10-14,15-19,20-24,25-29$, and $\geq 30$ ppt) ture and disease prevalence resulted in the following 
Table 2. Spearman's rank correlation coefficients $\left(\mathrm{r}_{\mathrm{S}}\right)$ for all parameters. The infection index was calculated for infected oysters per site. Shell lengths A and B refer to shell lengths of oysters used to determine condition indices and oysters used to determine disease intensity and prevalence, respectively. + : positive correlation $;-$ : negative correlation. ${ }^{*} p<0.10,{ }^{* *} p<0.05$

\begin{tabular}{|c|c|c|c|c|c|c|c|c|c|c|}
\hline & $\begin{array}{l}\text { Condition } \\
\text { index }\end{array}$ & $\begin{array}{l}\text { Infection } \\
\text { index }\end{array}$ & $\begin{array}{c}\text { Prevalence } \\
(\%)\end{array}$ & $\begin{array}{l}\mathrm{M} / \mathrm{F} \\
\text { ratio }\end{array}$ & $\begin{array}{l}\text { Salinity } \\
\text { (ppt) }\end{array}$ & $\begin{array}{l}\text { Shell ler } \\
\text { A }\end{array}$ & $\begin{array}{c}\text { gth }(\mathrm{mm}) \\
\text { B }\end{array}$ & $\begin{array}{l}\text { No. spat } \\
\text { (per } 100 \mathrm{~cm}^{2} \text { ) }\end{array}$ & $\begin{array}{l}\text { Temp. } \\
\left({ }^{\circ} \mathrm{C}\right)\end{array}$ & $\begin{array}{l}\text { Weight } \\
\text { (g) }\end{array}$ \\
\hline Condition index & & $-0.22^{*}$ & -0.11 & -0.04 & -0.07 & $-0.21^{*}$ & -0.11 & $-0.34^{* *}$ & +0.10 & -0.18 \\
\hline Infection index & $-0.22^{*}$ & & $+0.57^{* *}$ & $-0.25^{* *}$ & -0.10 & +0.06 & $+0.38^{* *}$ & $-0.35^{* *}$ & -0.03 & +0.05 \\
\hline Prevalence (\%) & -0.11 & $+0.57^{* *}$ & & $-0.23^{*}$ & -0.12 & -0.01 & $+0.33^{* *}$ & $-0.35^{* *}$ & -0.19 & $-0.25^{* *}$ \\
\hline $\mathrm{M} / \mathrm{F}$ ratio & -0.04 & $-0.25^{* *}$ & $-0.23^{*}$ & & -0.03 & -0.18 & -0.18 & +0.02 & $+0.32^{* *}$ & +0.13 \\
\hline Salinity (ppt) & -0.07 & -0.10 & -0.12 & -0.03 & & +0.05 & +0.08 & +0.11 & +0.13 & -0.16 \\
\hline Shell length A (mm) & $-0.21^{*}$ & +0.06 & -0.01 & -0.18 & +0.05 & & $+0.43^{* *}$ & -0.05 & +0.03 & $+0.50^{* *}$ \\
\hline Shell length B (mm) & -0.11 & $+0.38^{* *}$ & $+0.33^{* *}$ & -0.18 & +0.08 & $+0.43^{* *}$ & & -0.04 & -0.15 & -0.04 \\
\hline No. spat per $100 \mathrm{~cm}^{2}$ & $2^{2}-0.34^{* *}$ & $-0.35^{* *}$ & $-0.35^{* *}$ & +0.02 & +0.11 & -0.05 & -0.04 & & +0.05 & -0.08 \\
\hline Temperature $\left({ }^{\circ} \mathrm{C}\right)$ & +0.10 & -0.03 & -0.19 & $+0.32^{* *}$ & +0.13 & +0.03 & -0.15 & +0.05 & & $+0.27^{* *}$ \\
\hline Weight $(\mathrm{g})$ & -0.18 & +0.05 & $-0.25^{* *}$ & +0.13 & -0.16 & $+0.50^{* *}$ & -0.04 & -0.08 & $+0.27^{* *}$ & \\
\hline
\end{tabular}

\section{DISCUSSION}

Local prevalence appears to have remained high (mean $66 \%$ ), with $100 \%$ prevalence occurring at 12 of the 67 sites. Only one site did not have any detectable infection. Although no data were provided, Perkinsus marinus was considered widespread throughout coastal Georgia in 1967 (Hoese 1968). Prevalence specifically from Chatham County during the 1980s was 0 and $100 \%$ at the Wilmington River and Charles Creek, respectively. However, we found substantially lower infection intensities than those recorded in the 1980s (mean 3.9; Lewis et al. 1992) and 1990s (mean 3.2; O'Beirn et al. 1997), a period when known major $(60-70 \%)$ oyster mortalities occurred. One-third of all oysters examined across our study area were patently uninfected. Our maximum infection index was 1.83 (mean 0.47 , very light), and $90 \%$ of sites scored less than 1. Ford \& Tripp (1996) reported that during a $P$. marinus epizootic, one can expect most of the oysters to have advanced infection indices $(4,5$ on Mackin's scale, i.e. medium-medium heavy); however, Andrews (1988) reported that mortalities are likely when the mean infection index exceeds 1 (very light) in a population. This indicates that the risk of oyster mortalities in Chatham County, Georgia, is relatively low. Heritable resistance to the disease has been documented (Bushek 1994) and may be increasing in the area due to natural selection. However, our sampling was conducted in summer (mid-June) and was a single sampling event. Increased resistance cannot be considered without documentation of the entire seasonal pattern of infection. In the northeast, the prevalence and intensity of the disease are typically lowest between January and April and highest from August to November (Ford \& Tripp 1996). While seasonal patterns are less evident in the southeast (Craig et al. 1989), infection intensities often peak in the late summer/fall months
(O'Beirn et al. 1994, Bobo et al. 1997). Therefore, our survey may underestimate the degree of intensity possible. Additionally, the end of Georgia's drought in 2003 and the associated reduction in salinity levels may also explain the lower intensity noted in the present study. The mean annual salinity at Site 5 dropped substantially from 30.13 ppt in 2002 to 24.67 ppt in 2003, which approaches the mean annual salinity recorded for this location over the last 27 years (Fig. 1). Ragone \& Burreson (1993) reported that infection prevalences remained high for oysters maintained in salinity treatments ranging from 6 to $20 \mathrm{ppt}$, but that the oysters exposed to lower salinities experienced lower mortalities.

Water temperatures recorded during sampling across the study area ranged from 27 to $32^{\circ} \mathrm{C}$, the reported optimum range for Perkinsus marinus (Ford 1996). Although P. marinus has a broad tolerance to salinity (8-50 ppt), it is found most commonly in areas above 15 ppt (Craig et al. 1989). Our oysters were collected from areas with salinities ranging from 8 to 30 ppt. While temperature and salinity taken at each Chatham County site appeared to have some relation to disease prevalence and intensity, the correlations were not statistically significant. Many other studies in the south have similarly failed to detect a relationship (Craig et al. 1989, Lewis et al. 1992, Soniat 1996). Our data reflect only the instant of sampling and not the range or duration of salinities and temperatures that these oysters were subjected to. Lewis et al. (1992) suggested that the intertidal temperature regime is more relevant than just water temperature for understanding oyster physiology and disease in the southeast.

Oyster populations in this region are unique in that most occur in the intertidal zone. Georgia has the greatest tidal amplitude (average approximately $2 \mathrm{~m}$ ) along the eastern United States and Gulf of Mexico 
coastlines with the exception of upper coastal Maine. Air temperatures in coastal Georgia during the summer and fall months can often reach above $32^{\circ} \mathrm{C}$ (Carter 1967), and oysters exposed at low tide in direct sunlight can be expected to experience temperatures well above $38^{\circ} \mathrm{C}$. In addition, half of the annual precipitation (average $1.35 \mathrm{~m}$ ) occurs between June and September (Carter 1967). The extreme temperature and salinity fluctuations experienced in this environment might play a role in controlling parasites (Bushek et al. 1997, Dwyer \& Burnett 1996). Heat shock proteins (HSPs) were recently postulated by Encomio \& Chu (2005) as playing a role in protecting eastern oysters from pathogenic stress. Thermal stress in association with reduced condition post-spawning, protein denaturation, increased microbial pathogens, Vibrio spp., and disease are thought to result in the high summer mortalities observed in many regions (Encomio \& Chu 2005). Since increased levels of HSPs have been associated with enhanced thermal tolerance in oysters (Piano et al. 2002), it is thought that they might counteract the effects of thermal stress and act as a stimulant of the host's immune response. The range of intraspecific variation of HSP expression among eastern oysters is unknown, but variation might account for spatial differences in disease tolerance. Given the extreme temperatures to which intertidal oysters are subjected in Georgia, it is possible that they have adapted physiologically with increased levels of HSPs, which in turn provides a greater degree of tolerance of disease infection.

Some studies have shown that oysters growing in shallower waters or in the intertidal zone have a lower prevalence and intensity of infections (Volety et al. 2000). One theory is that these oysters have less time available for feeding and therefore exposure to infective cells. This same theory has been postulated to explain the lower prevalence and intensity of infection in younger smaller oysters (Ford \& Tripp 1996).

Parasites are an energetic drain on their host, competing for stored nutrients, and often resulting in retarded growth rates, low condition indices, and reduced reproductive capabilities (Barber et al. 1988, Craig et al. 1989, Paynter 1996). Recruitment rates as determined by spat settlement were negatively correlated with Perkinsus marinus prevalence and intensity across the study area. Since a significant negative correlation was detected between infection intensity and the overall health of oysters as expressed by a condition index, it is possible that oysters at sites with high levels of disease also had reduced fecundity. However, our sampling occurred during the spawning period when condition indices are naturally impaired and many confounding factors including water quality, oyster density, oyster size, patterns of water movement, and food availability can lead to spatial differences in recruitment rates.

Disease can interfere with reproductive processes, sometimes producing an abundance of males during the spawning season, which is less expensive energetically (Barber et al. 1988). An equal sex ratio was observed in the present study (383 males, 375 females); however, the male/female ratio per individual site was significantly and negatively correlated with dermo prevalence and intensity. This may be explained by the fact that these oysters are protandric hermaphrodites, and typically mature as males first; therefore, females are often older and have been exposed to parasites for longer periods resulting in heavier burdens. We identified a positive correlation between shell length and dermo prevalence and intensity, supporting this hypothesis.

Many other factors can affect the prevalence of this disease. Biological factors include oyster nutrition, reproduction and spawning, density, and scavenger (e.g. blue crabs, mud crabs, polychaetes, fish, oyster drills) abundance (Powell et al. 1996). Watershed dynamics, pollution, and land use patterns may also explain some of the variability observed over the study area (Craig et al. 1989, Paynter 1996).

Acknowledgements. This work was supported by a grant to A.P. by the Savannah Presbyterian Church M. K. Pentecost Ecology Trust Fund, and by the University of Georgia Marine Extension Service. The authors thank D. Thompson and N. Strachen for assisting in the collection and processing of specimens. Thanks to K. Schaefer and D. Atkinson for assisting in water quality data collection and to J. Nichols for assisting with the data analysis.

\section{LITERATURE CITED}

Andrews JD (1988) Epizootiology of the disease caused by the oyster pathogen Perkinsus marinus and its effects on the oyster industry. In: Fisher WS (ed) Disease processes in marine bivalve mollusks. Am Fish Soc Spec Publ 18

Barber BJ, Ford SE, Haskin HH (1988) Effects of the parasite MSX (Haplosporidium nelsoni) on oyster (Crassostrea virginica) energy metabolism. I. Condition index and relative fecundity. J Shellfish Res 7:25-31

Bobo MY, Richardson DL, Coen LD, Burrell VG (1997) A report on the protozoan pathogens Perkinsus marinus (Dermo) and Haplosporidium nelsoni (MSX) in South Carolina shellfish populations. Tech Rep No. 86. Publications of the SC Dept Nat Resources, Mar Research Div, Mar Resource Research Inst, Charleston, SC

Bushek D (1994) Dermo disease in the American oyster. Genetics of host-parasite interactions. PhD dissertation. Rutgers University, New Brunswick, NJ

Bushek D, Holley R, Kelly M (1997) Chlorine tolerance of Perkinsus marinus. J Shellfish Res 16(1):260

Carter HS (1967) Climatic summaries of resort areas-the Golden Isles of Georgia. US Dept Commerce, Climatography of the United States No. 21-9-2 
Craig MA, Powell EN, Fay RR, Brooks JM (1989) Distribution of Perkinsus marinus in Gulf coast oyster populations. Estuaries 12:82-91

Dwyer JJ, Burnett LE (1996) Acid base status of the oyster Crassostrea virginica in response to air exposure and to infections by Perkinsus marinus. Biol Bull (Woods Hole) 190:139-147

Encomio VG, Chu FLE (2005) Seasonal variation of heat shock protein 70 in eastern oysters (Crassostrea virginica) infected with Perkinsus marinus (Dermo). J Shellfish Res 24:167-175

Ford SE (1996) Range extension by the oyster parasite Perkinsus marinus into the northeastern United States: response to climate change. J Shellfish Res 15:45-56

Ford SE, MR Tripp (1996) Diseases and defense mechanisms. In: Kennedy VS, Newell RIE, Eble AF (eds) The eastern oyster: Crassostrea virginica. Maryland Sea Grant, College Park, MD, p 581-660

Hoese HD (1968) Studies of the parasitic oyster fungus Labyrinthomyxa sp. in Georgia salt waters. In: Linton TL (ed) Feasibility study of methods for improving oyster production in Georgia. Mar Fish Div, Georgia Game \& Fish Comm and University of Georgia Completion Report 2-10-R

Howard DW, Smith CS (1983) Histological techniques for marine bivalve mollusks. NOAA Tech Mem NMFSF/NEC-25

Johnson AS, Hillestad HO, Shanholtzer SF, Shanholtzer GF (1974) An ecological survey of the coastal region of Georgia. Wash Nat Park Ser Sci Monogr Ser No. 3

Kim Y, Powell EN, Wade TL, Presley BJ, Brooks JM (1999) Influence of climate change on interannual variation in contaminant body burden in Gulf of Mexico oysters. Mar Environ Res 48:459-488

Lawrence DR, Scott GI (1982) The determination and use of condition index of oysters. Estuaries 5:23-27

Lee RF, Frischer ME (2004) The decline of the blue crab. Am Sci 92:548-553

Lewis EJ, Kern FG, Rosenfield A, Stevens SA, Walker RL, Heffernan PB (1992) Lethal parasites in oysters from coastal Georgia with discussion of disease and management implications. Mar Fish Rev 54:1-6

Mackin JG, Owen HM, Collier A (1950) Preliminary note on the occurrence of a new protistan parasite, Dermocystid-

Editorial responsibility: Albert Sparks,

Seattle, Washington, USA ium marinum n. sp. in Crassostrea virginica (Gmelin). Science 111:328-329

O'Beirn FX, Heffernan PB, Walker RL (1994) Settlement of Crassostrea virginica: a tool for monitoring the aquatic health of the Sapelo Island National Estuarine Research Reserve. Mar Tech Rep 94-2, University of Georgia, Athens, GA

O'Beirn FX, Walker RL, Jansen ML (1997) Reproductive biology and parasite (Perkinsus marinus) prevalence in the eastern oyster, Crassostrea virginica, within a Georgia tidal river. J Elisha Mitchell Sci Soc 113:22-36

Paynter K (1996) The effects of Perkinsus marinus infection on physiological processes in the eastern oyster, Crassostrea virginica. J Shellfish Res 15:119-125

Piano A, Asirelli C, Caselli F, Fabbri E (2002) Hsp70 expression in thermally stressed Ostrea edulis, a commercially important oyster in Europe. Cell Stress Chaperones 7: 250-257

Powell EN, Ellis MS (1998) Perkinsus marinus Assay. In: Lauenstein GG, Canstillo YY (eds) Sampling and analytical methods of the National Status and Trends Program Mussel Watch Project: 1993-1996. Update. NOAA Tech Mem NOS ORCA 130:228-233

Powell EN, Klink JM, Hofmann EE (1996) Modeling diseased oyster populations II. Triggering mechanisms for Perkinsus marinus epizootics. J Shellfish Res 15:141-165

Quick JA, Mackin JG (1971) Oyster parasitism by Labyrinthomyxa marina in Florida. Fla Dept Nat Res Prof Papers Ser 13:1-55

Ragone LM, Burreson EM (1993) Effect of salinity on infection progression and pathogenicity of Perkinsus marinus in the eastern oyster, Crassostrea virginica (Gmelin). J Shellfish Res 12:1-7

Ray SM (1952) A culture technique for the diagnosis of infections with Dermocystidium marinum, Mackin Owen and Collier, in oysters. Science 166: 360-361

Soniat TM (1996) Epizootiology of Perkinsus marinus disease of eastern oysters in the Gulf of Mexico. J Shellfish Res 15:35-43

Volety AK, Perkins FO, Mann R, Hershberg PR (2000) Progression of diseases caused by the oyster parasites, Perkinsus marinus and Haplosporidium nelsoni, in Crassostrea virginica on constructed intertidal reefs. J Shellfish Res 19:341-347

Submitted: May 24, 2006; Accepted: August 7, 2006 Proofs received from author(s): November 29, 2006 